\title{
Effect of silk sericin pre-treatment on dyeability of woollen fabric
}

\author{
DOI: 10.35530/IT.072.02.1771
}

\section{ABSTRACT - REZUMAT \\ Effect of silk sericin pre-treatment on dyeability of woollen fabric}

Silk fibres consist of sericin and fibroin. 20-25\% of silk fibre is sericin. Sericin is biodegradable, antibacterial, and UV resistant. In this study, silk sericin protein was applied to wool fabric as a pre-treatment. Wool fabrics pre-treated with silk sericin were dyed with Eriofast Red $B$ and Eriofast Blue $3 R$ dyestuffs. Colour and reflectance measurements of the dyed wool samples were carried out. Washing, rubbing, light fastness properties were explored. Moreover, hydrophilicity, nitrogen content (Kjeldahl Method), FTIR and ESCA analysis were performed on the sericin applied wool fabric samples. Pre-treatment with sericin was found to increase the hydrophilicity level of wool fibres. Pre-treatment with silk sericin also increased the colour yield of wool fibre dyed with Eriofast Red B and Eriofast Blue $3 R$. It was determined that the wool fibre fabrics pre-treated with sericin displayed sufficient colour and colour fastness values even after dyeing at lower dyeing temperatures.

Keywords: silk sericin, wool, dyeing, fastness, Bombyx mori, biopolymer

Influența pretratării cu sericină din mătase asupra capacității de vopsire a țesăturilor din lână

Fibrele de mătase sunt formate din sericină și fibroină. Aproximativ 20-25\% din fibra de mătase este sericină. Sericina este biodegradabilă, antibacteriană și rezistentă la radiații UV. În acest studiu, proteina sericinei din mătase a fost aplicată pe țesătura din lână ca pretratament. Țesăturile din lână pretratate cu sericină din mătase au fost vopsite cu coloranți Eriofast Red B și Eriofast Blue 3R. S-au efectuat măsurători ale rezistenței culorii și reflectanței pentru probelor de lână vopsite. S-au analizat proprietățile de rezistență la spălare, la frecare și la lumină. Mai mult, hidrofilia, conținutul de azot (metoda Kjeldahl), analiza FTIR și ESCA au fost efectuate pe probele de țesătură din lână, pe care a fost aplicată sericina. S-a constatat că pretratamentul cu sericină a crescut nivelul de hidrofilie a fibrelor de lână. Tratamentul prealabil cu sericină din mătase a crescut, de asemenea, randamentul tinctorial al fibrelor de lână vopsite cu Eriofast Red B și Eriofast Blue 3R. S-a stabilit că țesăturile din fibră de lână pretratate cu sericină au indicat valori suficiente ale rezistenței culorii, chiar și după vopsire la temperaturi de vopsire mai scăzute.

Cuvinte-cheie: sericină din mătase, lână, vopsire, rezistența culorii, Bombyx mori, biopolimer

\section{INTRODUCTION}

Raw silk consists of $20-25 \%$ sericin and $70-75 \%$ fibroin [1]. These ratios vary according to the type of silkworm, care and feeding conditions, country and region where it grows. The formula of the sericin is $\mathrm{C}_{15} \mathrm{H}_{25} \mathrm{~N}_{5} \mathrm{O}_{8}$ [2]. There are significant differences between sericin and fibroin. For instance, sericin contains more hydroxyl and carboxyl groups than fibroin and the amorphous structure is much higher in the case of sericin when compared with fibroin [2]. As a result of both its amorphous structure and the hydroxyl and carboxyl groups contents, sericin dissolves in hot water, especially slightly alkaline hot water [3]. Since sericin is a layer that covers the fibroin protein and covers the bright, beautiful appearance of fibroin, sericin is usually removed before dyeing $[4,5]$. It is really significant to degum silk yarns completely (to remove sericin efficiently) when silk will be dyed to dark shades. Since, the traces of sericin could result in unlevelled dyeing. It is known that the degummed silk fiber displays higher luster and softer hand when compared with raw silk fiber [6]. In the removal of the sericin; different methods such as enzymatic, conventional soap and soapsoda methods can be applicable. Enzymatic, classical soap and soap-soda methods were compared and it was found that enzymatic processes led to better results than others $[4,7]$. In another study, it was reported that Savinase $\AA$ was the most suitable enzyme for sericin removal [8]. From the industrial point of view, sericin removal from the silk fibre can result in severe environmental pollution because of their rich organic contents $[9,10]$.

In the recent years, there is a tendency towards ecological processes and biochemicals instead of toxic chemicals in textile finishing processes. One of the largest candidates in the textile sector is the sericin [11]. The sericin displays high moisture absorption, antimicrobiality and UV protection properties [12, 13]. There are studies in the literature that sericin protein 
is applied to textile materials. Babu and Ravindra reported that the hygroscopic properties of polyester coated with sericin protein increased 5 times compared to untreated sample [14]. In the study of Haggag et al., in order to increase the printability of woollen fabric with acid, reactive and basic dyes, hydrogen peroxide-sodium sulfite and sericin was applied to wool fabrics [15]. Jassim et al. investigated the antimicrobial properties of the sericin obtained from Bombyx Mori silkworm silk. When treated with $2 \%$ sericin, there was a decrease in the proportion of bacteria [16]. In 2011, Khalifa et al. applied the extracted sericin to woollen fabric. As a result of the applications, water absorption showed a high value at $5 \%$ sericin concentration. Optimum antibacterial properties were determined at $\mathrm{pH} 3.8$ [17]. In the study conducted by Das et. al., sericin treated jute fibres were dyed with reactive dyes without salt [18]. In this research study, silk sericin protein was applied to wool fabric as a pre-treatment. Sericin pre-treated wool fabrics were dyed with Eriofast Red B and Eriofast Blue 3R dyestuffs. In here, it was investigated whether wool fibres pre-treated with sericin can be dyed at lower temperatures without the loss of colour yield.

\section{MATERIALS AND METHODS}

\section{Materials}

In this study, a plain bleached woven $100 \%$ wool fibre fabric with the weight of $150 \mathrm{~g} / \mathrm{m}^{2}$ (with 53.35 Stensby whiteness value) was utilized.

\section{Application (pre-treatment) of silk sericin and subsequent dyeing process}

Sericin pre-treatment was carried out in an Atac Lab-Dye HT machine with $5 \%$ Sericin (obtained from Bombyx mori silkworm, Sigma-Aldrich) and $25 \mathrm{~g} / \mathrm{l}$ $\mathrm{Na}_{2} \mathrm{SO}_{4}$ at a liqour ratio of 20:1 [17]. After pre-treatment with sericin, Atac Lab-Dye HT laboratory type dyeing machine was used for wool fabric dyeing operations. Exhaustion dyeing method for wool was carried out at $95^{\circ} \mathrm{C}$ for 60 minutes (figure 1).

Two different dyestuffs in red (Eriofast Red $B$ reactive dye, Huntsman) and blue (Eriofast Blue $3 R$ reactive dye, Huntsman) color and silk sericin (Bombyx mori (silkworm) Sigma-Aldrich) were used in this study. Apart from dyeing at $95^{\circ} \mathrm{C}$, Eriofast Red B dyestuff was also applied to pre-treated wool fabrics accord-

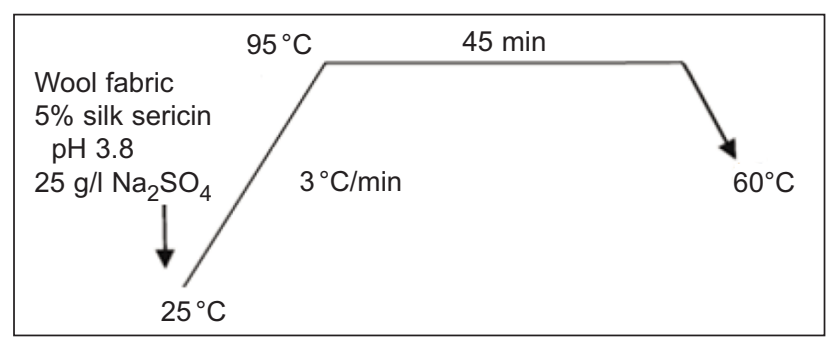

a ing to the same dyeing recipe at $75^{\circ} \mathrm{C}, 80^{\circ} \mathrm{C}, 85^{\circ} \mathrm{C}$. The dyed wool samples were firstly rinsed in cold water and then washed off at $45-50^{\circ} \mathrm{C}$ and $60^{\circ} \mathrm{C}$ for 10 minutes, respectively.

\section{Analysis and testing}

\section{Colorimetric measurement}

Stensby whiteness and yellowness values (E313 YI) of the sericin-pretreated wool fabric samples were determined. The average of the measurements was calculated from four different points from fabric samples. The CIE $L^{*}, a^{*}, b^{*}, C^{*}$, and $h^{\circ}$ coordinates were measured from the reflectance values at the appropriate wavelength of maximum absorbance for each dyed wool fabric sample with the utilization of a DataColor SpectraFlash 600 (Datacolor International, Lawrenceville, NJ, USA), spectrophotometer under illuminant D65, using a $10^{\circ}$ standard observer.

Fourier transform infrared spectroscopy (FTIR)

IR spectra were taken to investigate the changes in the surface structure and chemical structure of the treated wool fibres. Perkin Elmer Spectrum TwoTM ATR/FTIR instrument was used for FTIR analysis. From the obtained spectra, characteristic bands were examined and sericin treated and sericin untreated wool samples were compared.

Nitrogen determination by Kjeldahl method

The Kjeldahl method is generally utilized to determine the nitrogen content in organic and inorganic samples. Kjeldahl method was used to determine the nitrogen content of the sericin applied and nonapplied wool fabric samples. Nitrogen was determined by Gerhardt Kjeldahlterm Vaposdest. In this method, the nitrogen content of the organic materials containing nitrogen is converted to ammonia to determine the nitrogen content of the sample.

\section{ESCA Test Analysis}

ESCA (Electron Spectroscopy for Chemical Analysis), also known as XPS (X-ray Photoelectron Spectroscopy), is the energy analysis of photoelectrons constituted at the surface of the fabric sample by X-Ray irradiation.

\section{Hydrophilicity determination}

Hydrophilicity property (water absorption property) of the treated and untreated wool fabric samples was determined according to TS 866 standard. This test is based on measuring the absorption time of the water droplets dropped onto the textile material. Moreover,

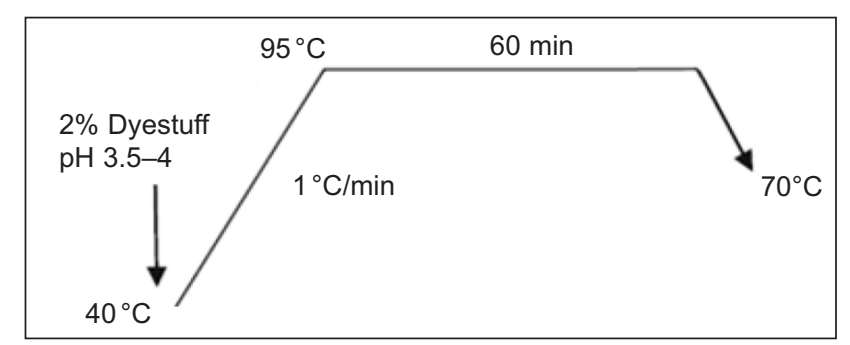

b

Fig. 1. Silk sericin pre-treatment process and following wool dyeing process: $a$ - sericin pre-treatment profile; $b$-dyeing profile 
sinking test was also applied to the treated and untreated wool fabric samples according to TS 629 BS EN 14697 standard. The essence of this method is based on the determination of the immersion time of the sample deposited on the water by completely absorbing the water.

Dyeing uptake analysis

The absorbance values of the dye solutions (before and after dyeing process) were measured by utilizing a Perkin Elmer UV-Visible spectroscopy instrument. $\lambda_{\text {max }}$ values of the dyebath containing Eriofast Red $B$ reactive dye and Eriofast Blue $3 R$ reactive dye were $515 \mathrm{~nm}$ and $590 \mathrm{~nm}$, respectively. The absorbance values of the studied reactive dyes at their $\lambda_{\text {max }}$ points were considered for dye-uptake calculations. The percentage reactive dye uptake by the wool fabrics was calculated using below equation:

$$
\text { Dye Uptake }(\%)=\frac{\left(A_{b}-A_{a}\right)}{A_{b}} \times 100
$$

where $A_{b}$ is the absorbance of the dye bath before dyeing process, $A_{a}$ - the absorbance of dye bath after dyeing process.

Colour fastness determination

Wash, rub and light fastness properties were investigated. Wash fastness to domestic laundering (C06) was determined according to ISO 105:C06 A2S test in a M228 Rotawash machine (SDL ATLAS, UK). The wash fastness test was performed at $40^{\circ} \mathrm{C}$. Both dry and wet rub fastness tests were performed according to the ISO 105: X12 protocol. Colour fastness of the dyed wool fabrics to washing and to dry \& wet rubbing was determined via using ISO grey scales.

\section{RESULTS AND DISCUSSIONS}

\section{Effects of silk sericin pre-treatment on wool fabric}

The whiteness values of the sericin applied wool fabrics decreased by about 2 points compared to the untreated wool fabric. In parallel with the decrease in whiteness degree, the yellowness values of the sericin applied wool fabrics increased (table 1).

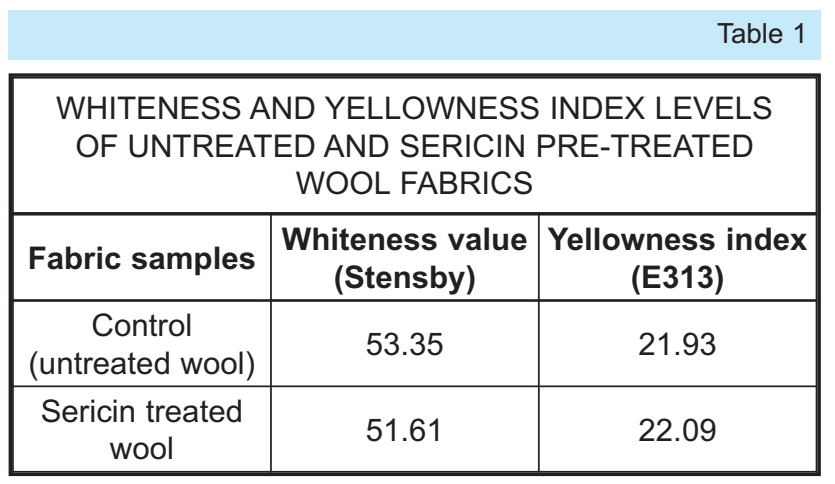

In the literature, the nitrogen content of wool fibre is given as in the range of $16 \%-17 \%[19,20]$. The nitrogen content of the sericin applied wool fibre was measured as 18\% (table 2). Therefore, the nitrogen content of the wool fibres pre-treated with sericin protein via exhaustion method increased (table 2). The increase in nitrogen content of the wool fibre fabric indicates that the application of sericin protein to wool fibres was successful.

Table 2

\begin{tabular}{|c|c|}
\hline \multicolumn{2}{|c|}{ NITROGEN DETERMINATION BY KJELDAHL METHOD } \\
\hline Fabric samples & Amount of Nitrogen (\%) \\
\hline Control (untreated wool) & 16 \\
\hline Sericin treated wool & 18 \\
\hline
\end{tabular}

ESCA analyses were performed to determine the changes in surface characteristics of wool fibres before and after sericin pre-treatment. The results of this analysis are shown in figure 2.

The $N$ content (\%) increased in the structure of wool fibres when treated with sericin (figure 2). The nitrogen content of sericin-treated wool fibres increased from $6.5 \%$ to $6.6 \%$.

Both hydrophilicity test methods showed that the hydrophilicity property of sericin treated wool fabrics improved when compared to untreated wool fabric (table 3).
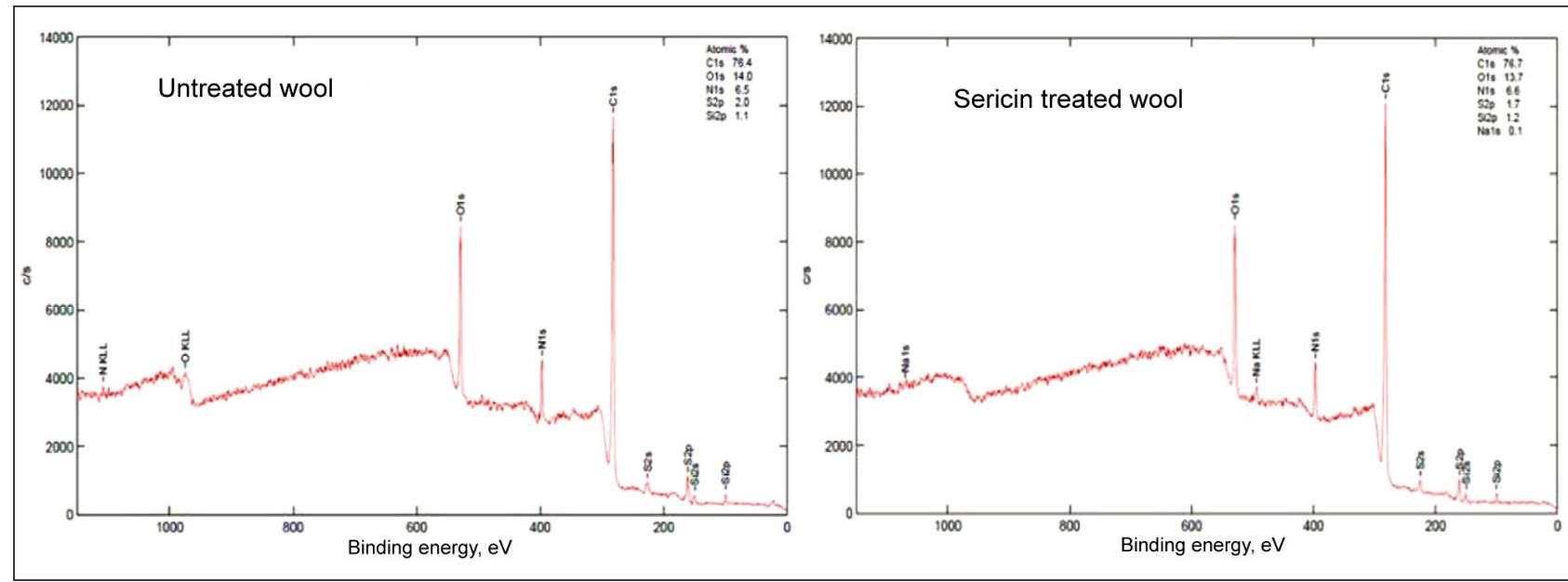

Fig. 2. ESCA analysis graphs of sericin pre-treated and un-treated wool fabrics 
Table 3

\section{HYDROPHILICITY PROPERTIES OF UNTREATED} AND SERICIN TREATED WOOL FABRICS

\begin{tabular}{|l|c|c|}
\hline $\begin{array}{c}\text { Hydrophilicity } \\
\text { test methods }\end{array}$ & $\begin{array}{c}\text { Control } \\
\text { (untreated wool) }\end{array}$ & $\begin{array}{c}\text { Sericin treated } \\
\text { wool }\end{array}$ \\
\hline $\begin{array}{l}\text { Sinking test } \\
\text { method (sinking } \\
\text { time in seconds) }\end{array}$ & 245 & 90 \\
\hline $\begin{array}{l}\text { Drop test method } \\
\text { (wetting time } \\
\text { in seconds) }\end{array}$ & 337 & 115 \\
\hline
\end{tabular}

According to the FTIR spectrum of the sericin pretreated wool fibre; the number of $\mathrm{H}$ and $\mathrm{OH}$ groups increased at $3000 \mathrm{~cm}^{-1}$ wavelength with pre-treatment of sericin (figure 3 ).

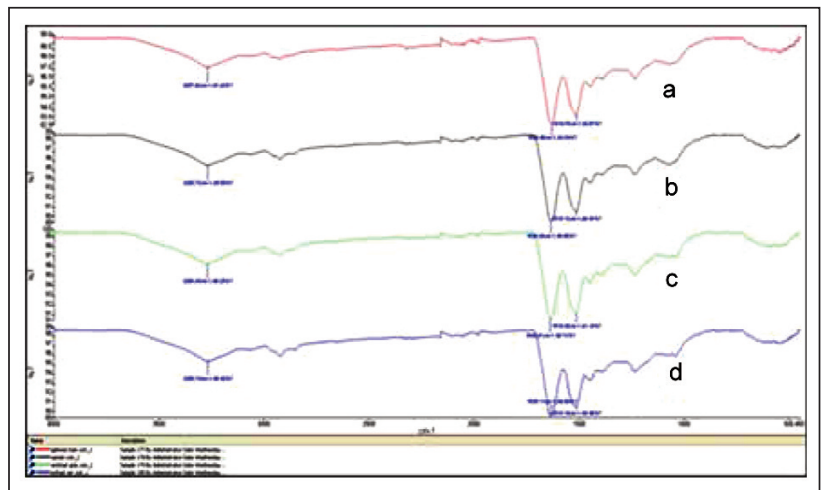

Fig. 3. FTIR graph of: $a$ - untreated wool fabric (as control); $b$ - sericin pre-treated wool fabric, $c$ - untreated dyed wool fabric; $d$-sericin pre-treated and dyed wool fabric

\section{Effects of silk sericin treatment on colour strength and fastness properties}

Dye-uptake results

In order to determine the effect of sericin pre-treatment on reactive dye uptake, pre-dyeing and post-dyeing samples were taken from dye baths and dye-uptake (\%) values were calculated and shown in table 4. Table 4 shows that pre-treatment with sericin increases the amount of dyestuff absorbed by wool fibres. In earlier study, it was reported that the functional groups present in sericin i.e. $-\mathrm{NH}_{2},-\mathrm{COOH}$, and $-\mathrm{OH}$ increased the reactivity of cotton fibre fabric towards natural dye that subsequently improved the dye-uptake results [21]. It is known that the more amine groups results in more positive places on the fibre material as a place to bind the available reactive dyes [22]. By applying the sericin containing $\mathrm{NH}_{2}$, $-\mathrm{COOH}$, and $-\mathrm{OH}$ groups [20] as pre-treatment to wool fibre, the number of functional groups that will make covalent bonds with reactive dyestuffs in wool fibre increased [22] and consequently dye-uptake increased. The K/S and $L^{*}, a^{*}, b^{*}, h^{\circ}$ and $C^{*}$ values of the sericin pre-treated and untreated dyed wool fabrics are given in table 5 .

The $L^{*}$ (Lightness / Darkness; Black $=0$ and White $=$ 100) value of the woollen sample dyed with Eriofast Red B after pre-treatment with sericin protein was lower than the untreated sample (table 5). The colour is darker in the case of sericin pre-treated wool fabric than the untreated sample. The colour strength of the sericin pre-treated wool fabric (K/S value of 14.15) increased by $57 \%$ compared to the colour strength of the sericin-pre-treated wool sample (K/S value of 9.03) (table 5). The sericin pre-treated wool fabric is more red $\left(a^{*}\right.$; Red $=$ Positive Value $\left(+a^{*}\right)$ and Green $=$ Negative Value $\left.\left(-a^{*}\right)\right)$ and more yellow $\left(b^{*}\right.$; Yellow $=$ Positive Value $\left(+b^{*}\right)$ and Blue $=$ Negative Value $\left.\left(-b^{*}\right)\right)$ than the sericin untreated wool fabric. Chroma $\left(C^{*}\right)$ and hue angle $\left(h^{\circ}\right)$ values of sericin treated wool fabric were higher than those of untreated wool fabric counterparts (table 5).

In the case of wool fibres pre-treated with sericin and dyed; $L^{*}$ (lightness-darkness) value decreased, and therefore leading to higher colour strength. The colour strength value (K/S value of 9.37) of the pre-treated

DYE-UPTAKE RESULTS OF SERICIN PRE-TREATED AND UNTREATED WOOL FABRICS

\begin{tabular}{|c|c|c|c|c|}
\hline Dye Type & \multicolumn{2}{|c|}{ Eriofast Red B Reactive Dye } & \multicolumn{2}{c|}{ Eriofast Blue 3R Reactive Dye } \\
\hline Fabric Type & control (untreated wool) & sericin treated wool & control (untreated wool) & sericin treated wool \\
\hline$\lambda_{\text {max }}(\mathrm{nm})$ & \multicolumn{2}{|c|}{515} & 66 & 590 \\
\hline Dye uptake (\%) & 62 & 99 & 91 \\
\hline
\end{tabular}

Table 5

\begin{tabular}{|c|l|c|c|c|c|c|c|}
\hline \multicolumn{8}{|c|}{ COLORIMETRIC PROPERTIES OF SERICIN PRE-TREATED WOOL FABRICS DYED AT 95 ${ }^{\circ} \mathrm{C}$} \\
\hline \multirow{2}{*}{ Dye type } & \multicolumn{1}{|c|}{ Fabric type } & $\begin{array}{c}\text { Colour } \\
\text { strength (K/S) }\end{array}$ & $\mathbf{L}^{*}$ & $\mathbf{a}^{*}$ & $\boldsymbol{b}^{*}$ & $\boldsymbol{h}^{\circ}$ & $\boldsymbol{C}^{*}$ \\
\hline \multirow{2}{*}{ Eriofast Red B } & control untreated wool) & 9.03 & 46.53 & 52.65 & 4.53 & 52.85 & 4.92 \\
\cline { 2 - 9 } & sericin treated wool & 14.15 & 41.03 & 55.47 & 10.5 & 56.45 & 10.72 \\
\hline \multirow{2}{*}{ Eriofast Blue 3R } & control (untreated wool) & 6.81 & 41.30 & 2.28 & -36.64 & 273.45 & 36.66 \\
\cline { 2 - 8 } & sericin treated wool & 9.37 & 36.92 & 4.63 & -37.53 & 277.14 & 37.57 \\
\hline
\end{tabular}


with sericin and dyed wool fabric with Eriofast Blue $3 R$ is higher than the colour yield value of the nonpre-treated and dyed wool fabric (6.81). Sericin pretreated wool fibres; $L^{*}$ (lightness-darkness) value decreased, ie darkened colour. $a^{*}$ increased; The sericin pre-treated sample is redder than the sericin untreated sample. $b^{*}$ value of the series of pre-treated wool fabric decreased; The series has shifted to more blue than the sample without pre-treatment. The $C^{*}$ value of the sericin-treated wool fabric (Chroma, Saturation) and $h^{\circ}$ (hue angle) increased compared to the untreated fabric (table 5). Sericin pre-treated samples were redder (with higher $a^{*}$ values) than sericine untreated samples. The $b^{*}$ value of the pre-treated woollen fabric of the series decreased. Therefore, the colour of the sericin pretreated wool fabric shifted to a more blue colour than the sericin-untreated sample (table 5).

The dyeing was also carried out at $75^{\circ} \mathrm{C}, 80^{\circ} \mathrm{C}$ and $85^{\circ} \mathrm{C}$ (apart from $95^{\circ} \mathrm{C}$ ) with the idea that wool fibre could be dyed at lower temperatures without damaging the fibres and as a result, energy and time savings could be achieved. The colour characteristics of the dyed samples are given in table 6 . The colour strength of the untreated wool sample and dyed with Eriofast Red $\mathrm{B}$ at $95^{\circ} \mathrm{C}$ was 9.03 and the colour strength of the sericin pre-treated and dyed wool sample was measured as 14.05 . The colour strength value of pre-treated and dyed wool fabric at $85^{\circ} \mathrm{C}$

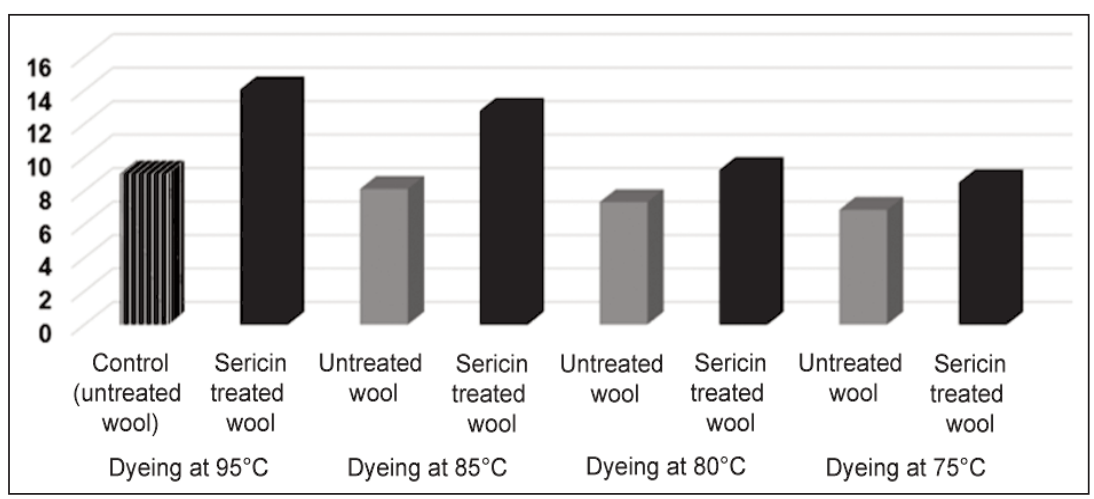

Fig. 4. Colour strength (K/S) of pre-treated or untreated and dyed (at different dyeing temperatures) wool fabrics
(K/S value of 12.78) was higher than the colour strength of untreated and dyed sample at $95^{\circ} \mathrm{C}(\mathrm{K} / \mathrm{S}$ value of 9,03 ) (table 6 ). When pre-treated with sericin, it is also possible to dye wool fabric at $85^{\circ} \mathrm{C}$ with high colour yields (table 6 and figure 4).

The sericin pre-treated wool fibre dyed at $80^{\circ} \mathrm{C}(\mathrm{K} / \mathrm{S}$ value of 9.24) displayed approximately similar colour strength value with the un-pre-treated wool fabric dyed at $95^{\circ} \mathrm{C}(\mathrm{K} / \mathrm{S}$ value of 9.03 ) (table 6 and figure 4). When the dyeing temperature is lowered to $75^{\circ} \mathrm{C}$; the colour strength of sericin treated wool fabric was measured as K/S of 8.50. This value is less than the colour strength value of the sericin un-treated reference wool fabric dyed at $95^{\circ} \mathrm{C}(\mathrm{K} / \mathrm{S}$ value of 9.03).

According to the results obtained; with the application of sericin protein as a pre-treatment, it is possible to dye wool fibres at lower temperatures, i.e. at $85^{\circ} \mathrm{C}$ or at $80^{\circ} \mathrm{C}$ instead of $95^{\circ} \mathrm{C}$. However, in determining the optimum dyeing temperature, fastness properties as well as colour yield should be taken into consideration.

\section{Colour fastness performance of dyed woollen fabrics}

The rubbing fastness results of the woollen fabric samples dyed at different temperatures $\left(95^{\circ} \mathrm{C}, 85^{\circ} \mathrm{C}\right.$, $80^{\circ} \mathrm{C}, 75^{\circ} \mathrm{C}$ ) are the same for sericin pre-treated and un-pre-treated samples (table 7). Although the colour yields of sericin pre-treated wool fibres are higher than the colour yields of sericin untreated wool fibres, it is noteworthy that the rubbing fastness properties of the sericin pre-treated wool fibres were at same level with the rubbing fastness properties of the untreated wool fibres (table 7).

Washing fastness values for cotton fibre staining of wool fabrics dyed at $80^{\circ} \mathrm{C}$ and $75^{\circ} \mathrm{C}$ were lower than those of wool fabrics dyed at $85^{\circ} \mathrm{C}$ and $95^{\circ} \mathrm{C}$ (table 8). Wool fabrics dyed with Eriofast Red $\mathrm{B}$ at $80^{\circ} \mathrm{C}$ and $75^{\circ} \mathrm{C}$ started to contaminate cotton fibre with $4 / 5$ and 4 grey scale rating, respectively (table 8 ).

Table 6

COLORIMETRIC PROPERTIES OF PRETREATED (WITH SERICIN) AND DYED WOOL FABRICS AT DIFFERENT TEMPERATURES

\begin{tabular}{|c|l|c|c|c|c|c|c|}
\hline $\begin{array}{c}\text { Dyeing temperature } \\
\text { (Dyed with Eriofast } \\
\text { Red B) }\end{array}$ & \multicolumn{1}{|c|}{ Fabric type } & $\begin{array}{c}\text { Colour strength } \\
\text { (K/S) }\end{array}$ & $\boldsymbol{L}^{*}$ & $\boldsymbol{a}^{*}$ & $\boldsymbol{b}^{*}$ & $\boldsymbol{h}^{\circ}$ & $\boldsymbol{C}^{*}$ \\
\hline \multirow{2}{*}{$95^{\circ} \mathrm{C}$} & Control (untreated wool) & 9.03 & 46.53 & 52.65 & 4.53 & 52.85 & 4.92 \\
\cline { 2 - 8 } & Sericin treated wool & 14.15 & 41.03 & 55.47 & 10.50 & 56.45 & 10.72 \\
\hline \multirow{2}{*}{$85^{\circ} \mathrm{C}$} & Untreated wool & 8.11 & 45.99 & 54.44 & 6.04 & 54.78 & 6.33 \\
\cline { 2 - 8 } & Sericin treated wool & 12.78 & 42.37 & 56.07 & 10.07 & 56.99 & 10.19 \\
\hline \multirow{2}{*}{$80^{\circ} \mathrm{C}$} & Untreated wool & 7.32 & 48.70 & 60.30 & 10.83 & 61.04 & 10.88 \\
\cline { 2 - 8 } & Sericin treated wool & 9,24 & 47.43 & 61.55 & 11.30 & 62.02 & 10.39 \\
\hline \multirow{2}{*}{$75^{\circ} \mathrm{C}$} & Untreated wool & 6.86 & 52.10 & 58.90 & 8.82 & 60.01 & 8.06 \\
\cline { 2 - 8 } & Sericin treated wool & 8.50 & 49.49 & 61.16 & 10.24 & 62.10 & 10.02 \\
\hline
\end{tabular}




\begin{tabular}{|c|c|c|c|c|c|c|c|}
\hline \multicolumn{8}{|c|}{ RUB FASTNESS PROPERTIES OF PRETREATED AND DYED WOOL FABRICS } \\
\hline \multirow{3}{*}{ Dyestuff } & \multirow{3}{*}{$\begin{array}{c}\text { Dyeing } \\
\text { temperature }\end{array}$} & \multirow{3}{*}{$\begin{array}{c}\mathrm{K} / \mathrm{S} \\
\text { (untreated } \\
\text { wool) }\end{array}$} & \multirow{3}{*}{$\begin{array}{c}\text { K/S } \\
\text { (sericin } \\
\text { pretreated } \\
\text { wool) }\end{array}$} & \multicolumn{4}{|c|}{ Rub fastness (X12) (cotton staining) } \\
\hline & & & & \multicolumn{2}{|c|}{ Wet $^{*}$} & \multicolumn{2}{|c|}{ Dry* } \\
\hline & & & & $\begin{array}{c}\text { untreated } \\
\text { wool }\end{array}$ & $\begin{array}{c}\text { sericin } \\
\text { pretreated } \\
\text { wool }\end{array}$ & $\begin{array}{c}\text { untreated } \\
\text { wool }\end{array}$ & $\begin{array}{c}\text { sericin } \\
\text { pretreated } \\
\text { wool }\end{array}$ \\
\hline Eriofast Red B & $95^{\circ} \mathrm{C}$ & 9.03 & 14.15 & 3 & 3 & 4 & 4 \\
\hline Eriofast Red B & $85^{\circ} \mathrm{C}$ & 8.11 & 12.78 & $3 / 4$ & $3 / 4$ & $4 / 5$ & $4 / 5$ \\
\hline Eriofast Red B & $80^{\circ} \mathrm{C}$ & 7.32 & 9.24 & $3 / 4$ & $3 / 4$ & $4 / 5$ & $4 / 5$ \\
\hline Eriofast Red B & $75^{\circ} \mathrm{C}$ & 6.86 & 8.50 & $3 / 4$ & $3 / 4$ & $4 / 5$ & $4 / 5$ \\
\hline Eriofast Blue 3R & $95^{\circ} \mathrm{C}$ & 6.81 & 9.37 & $3 / 4$ & $3 / 4$ & 5 & 5 \\
\hline
\end{tabular}

* Intermediate rating with underlined numbers indicates that the specimen's staining tended to be towards the underlined end of the range, and an underlined figure indicates that the grading was probably within a 0.25 point of that value.

\begin{tabular}{|c|c|c|c|c|c|c|c|c|}
\hline \multicolumn{9}{|c|}{ WASH FASTNESS PROPERTIES OF PRETREATED AND DYED WOOL FABRICS } \\
\hline \multirow{2}{*}{ Dye Type } & \multirow{2}{*}{$\begin{array}{c}\text { Dyeing } \\
\text { temperature }\end{array}$} & \multirow{2}{*}{ Treatment* } & \multicolumn{6}{|c|}{ Wash fastness staining (C06-A2S) } \\
\hline & & & Wool & Polyacrylic & Polyester & Nylon & Cotton & Acetate \\
\hline \multirow{2}{*}{$\begin{array}{l}\text { Eriofast } \\
\text { Red B }\end{array}$} & \multirow{2}{*}{$95^{\circ} \mathrm{C}$} & - & 5 & 5 & 5 & 5 & 5 & 5 \\
\hline & & + & 5 & 5 & 5 & 5 & 5 & 5 \\
\hline \multirow{2}{*}{$\begin{array}{l}\text { Eriofast } \\
\text { Red B }\end{array}$} & \multirow{2}{*}{$85^{\circ} \mathrm{C}$} & - & 5 & 5 & 5 & 5 & 5 & 5 \\
\hline & & + & 5 & 5 & 5 & 5 & 5 & 5 \\
\hline \multirow{2}{*}{$\begin{array}{l}\text { Eriofast } \\
\text { Red B }\end{array}$} & \multirow{2}{*}{$80^{\circ} \mathrm{C}$} & - & 5 & 5 & 5 & 5 & $4 / 5$ & 5 \\
\hline & & + & 5 & 5 & 5 & 5 & $4 / 5$ & 5 \\
\hline \multirow{2}{*}{$\begin{array}{l}\text { Eriofast } \\
\text { Red B }\end{array}$} & \multirow{2}{*}{$75^{\circ} \mathrm{C}$} & - & 5 & 5 & 5 & 5 & 4 & 5 \\
\hline & & + & 5 & 5 & 5 & 5 & 4 & 5 \\
\hline \multirow{2}{*}{$\begin{array}{l}\text { Eriofast } \\
\text { Blue 3R }\end{array}$} & \multirow{2}{*}{$95^{\circ} \mathrm{C}$} & - & 5 & 5 & 5 & 5 & 5 & 5 \\
\hline & & + & 5 & 5 & 5 & 5 & 5 & 5 \\
\hline
\end{tabular}

* - untreated wool; + sericin treated wool

Thanks to the application of the sericin protein as a pre-treatment, the wool fibre can be dyed at lower dyeing temperatures (for instance: $10^{\circ} \mathrm{C}$ lower; $85^{\circ} \mathrm{C}$ versus $95^{\circ} \mathrm{C}$ ) with good level of colour fastness.

\section{CONCLUSIONS}

Sericin is an amorphous and globular protein and constitutes 25 to $30 \%$ of the silk proteins. In this study, the effects of biodegradable, antibacterial, UV resistant silk sericin protein on the dyeing of wool fabrics were investigated. It was determined that the whiteness of the sericin pre-treated wool fabrics decreased by 2 points but the hydrophilicity values improved. Eriofast Red B and Eriofast Blue 3R reactive dyes were applied on sericin pre-treated and non-pre-treated wool fabrics. It was determined that the colour strengths of wool fabrics pre-treated with sericin increased in the case of both reactive dyes.
The rub fastness results of the wool fabric samples dyed at different temperatures $\left(95^{\circ} \mathrm{C}, 85^{\circ} \mathrm{C}, 80^{\circ} \mathrm{C}\right.$, $75^{\circ} \mathrm{C}$ ) are the same for sericin pre-treated and unpre-treated samples. Washing fastness decreased for wool fabrics dyed at $80^{\circ} \mathrm{C}$ and $75^{\circ} \mathrm{C}$. With the application of the sericin protein as a pre-treatment, it was determined that the wool fabric could be dyed with Eriofast Red $\mathrm{B}$ reactive dye at $10^{\circ} \mathrm{C}$ lower dyeing temperature $\left(85^{\circ} \mathrm{C}\right)$ leading to high colour strength and good colour fastness levels. Overall, sericin pretreated and dyed wool fibre fabrics displayed sufficient colour and colour fastness values even after dyeing at lower dyeing temperatures.

\section{ACKNOWLEDGEMENT}

Authors thank to Pamukkale University for their support. This paper was supported by Pamukkale University BAP (Scientific research project) Project No: 2015FBE017.

\section{REFERENCES}

[1] Karmakar, S.R., Chemical Technology in The Pre-Treatment Process Of Textiles, In: Elsevier Science B.V., 1999

[2] Yazıcıoğlu, G., Gülümser, G., Ipek ve Diğer Salgı Lifleri, In: E.Ü. Mühendislik Fakültesi Ders Kitapları Yayın, 1993, 27

[3] Aniş, P., Tekstil Ön Terbiyesi, In: Alfa Akademi Basım Dağıtım, Bursa, 2005 
[4] Duran, K., Özdemir, D., ve Namlıgöz, E.S., Ipek Liflerindeki Serisinin Enzimatik Olarak Uzaklaştırılması, In: Tekstil ve Konfeksiyon, 2007, 3, 182-186

[5] Tarakçığlu, I., Tekstil Terbiyesi ve Makineleri, Cilt, 1979, 2

[6] Ahsen, K.M., Dyeing of Wool and Silk Fibres with a Conductive Polyelectrolyte and Comparing Their Conductance, Report no. 2011.7.10, In: Masters in Textile Technology University of Boras, 2011, Available at: http://www.divaportal.org/smash/get/diva2:1308230/FULLTEXT01.pdf [Accessed on November 2019]

[7] Nargunamani, M., Selvakumar, N., Degumming of Silk, In: Colourage, 2002, 43-47

[8] Atav, R., Ekinci, S., Namırtı, O., Ipekteki Serisin Artıklarının Giderilmesinde En Uygun Aktif Merkeze Sahip Proteaz Enziminin Belirlenmesi, In: XIII. Uluslararası İzmir Tekstil ve Hazır Giyim Sempozyumu, İzmir, 2014

[9] Capar, G., Aygun, S.S., Gecit, M.R., Treatment Of Silk Production Wastewaters By Membrane Processes For Sericin Recover, In: J Memb Sci., 2008, 325, 2, 20-931

[10] Mowafi, S., El-Kheir, A.A., Taleb, M.A, El-Sayed, H., Keratin and Sericin: State of the Art and Future Outlook, In: Der Pharma Chemica, 2016, 8, 21, 22-30, http://www.derpharmachemica.com/archive.htm

[11] Rajendran, R., Balakumar, C., Sivakumar, R.T., Amruta, N., Extraction and application of natural silk protein sericin from Bombyx mori as antimicrobial finish for cotton fabrics, In: The Journal of The Textile Institute, 2011, 103, 4, 458-462

[12] Gupta, D., Chaudhary, H., Gupta, C., Sericin-based polyester textile for medical applications, In: The journal of The Textile Institute, 2015, 106, 4, 366-376

[13] Saha, J., Mondal, M.I.H., Sheikh, M.R.K., Habib, M.A., Extraction, Structural and Functional Properties of Silk Sericin Biopolymer from Bombyx mori Silk Cocoon Waste, In: J Textile Sci Eng, 2019, 9, 1, https://doi.org/10.4172/2165-8064.1000390

[14] Babu, K.M., Ravindra, K.B., Bioactive Antimicrobial Agents For Finishing of Textiles for Health Care Products, In: The Journal of The Textile Institute, 2015, 106,7, 706-717

[15] Haggag, K., Kantouch, F., Allam, O.G., El-Sayed, H., Improving Printability of Wool Fabrics Using Sericin, In: Journal of Natural Fibers, 200, 6, 3, 236-247

[16] Jassim, K., Al-Saree, O., Study of the Antimicrobial Activity of Silk Sericin From Silkworm Bombyx Mori, In: Dept. of Basic Science, 2010, 23, 2

[17] Khalifa, I.B., Ladhari, B., Touay, M., Application of sericin to modify textile supports, In: The Journal of The Textile Institute, 2011, 103, 4, 370-377

[18] Das, D., Bakshi, S., Bhattacharya, P., Modification of Jute With Sericin For Improvement In Dyeing, In: International Journal of Latest Trends in Engineering and Technology, http://dx.doi.org/10.21172/1.122.02

[19] Akcalı, K., Blut, M.O., Plazma Teknolojilerinin Yün Elyafı Üzerindeki Etkileri Üzerine Bir Inceleme, In: Mühendislik Bilimleri ve Tasarım Dergisi, 2012, 2, 1, 65-72

[20] Simpson, W., Crawshaw, G.H., Wool: Science and Technology, In: The Textile Institute, 2008

[21] Bhandari, B., Saroj, S., Singh, J., Neelam, M.R., Effect of sericin treatment conditions on dye ability of cotton fabric, In: Journal of Applied and Natural Science, 2018, 10, 1, 102-106

[22] Umam, K., Fitria, N., Surface Modification of Polyester Fiber With Sericin for Cold Reactive Dyeing, In: AIP Conference Proceedings, 2018, https://doi.org/10.1063/1.5082406

\section{Authors: \\ CENGIZ ONUR ESER, ARZU YAVAS}

Pamukkale University, Engineering Faculty, Textile Engineering Department, 20160, Denizli, Turkey

Corresponding author:

ARZU YAVAS

e-mail: aozerdem@pau.edu.tr 